\title{
Peningkatan Ekonomi Melalui Pengolahan Tepung Mocaf Pada Masa Pandemi Covid-19
}

\section{${ }^{1}$ Dede R. Oktini, ${ }^{2}$ Rahmat Effendi, ${ }^{3}$ Yudha Dwi Nugraha, ${ }^{4}$ Rezi Muhamad Taufik Permana}

\author{
${ }^{1,3,4}$ Fakultas Ekonomi \& Bisnis, ${ }^{2}$ Fakultas Dakwah, Universitas Islam Bandung, \\ Jl. Tamansari No. 1 Bandung 40116 \\ email:1'dede.r.oktini@gmail.com
}

\begin{abstract}
PKM is aimed at cassava farmers and the village community of Rende. The role of farmers and businesses processed foodis very much needed considering the economic condition has decreased since the Covid-19, meanwhile government changed the direction of development by prioritizing economic. Farmers complain that it is difficult to sell until difficult to improve their welfare. The purpose of PKM so that the harvest can be sold in product, in the form of mocaf flour with the intention that it is not difficult to sell and the price is higher. The target audience is those who need and are willing to be fostered in the business, goal ultimateis the establishment of sustainable business. The method of activity is tutorials and training. Based on the results of PKM assistance, there are 7 participants who are serious about doing business through partnerships and marketed, so that the harvest is utilized and sold because Mocaf can last 1 year. The price of cassava hasn't increased because it's still from their own plantations and the amount of production is limited. Marketing has been done online, but has not been able to meet demand due to production constraints. Keywords: Farmers, Mocaf, Price, welfare

Abstrak. PKM ini ditujukan pada petani singkong dan masyarakat desa RendeBandung Barat. Peran petani dan pelaku usaha makanan olahan sangat dibutuhkan mengingat kondisi perekonomian desa Rende - mengalami penurunan semenjak mewabahnya Covid-19, sementara itu pemerintah daerah mengubah arah pembangunan dengan memprioritaskan recovery perekonomian. Petani mengeluhkan sulitnya menjual hasil panen, tengkulak hanya membeli sebagian dengan harga rendah sehingga sisa panen tidak termanfaatkan, kemudian dibuat gaplek sebagai pakan ternak berharga murah. Akibatnya petani sulit meningkatkan kesejahteraannya. Tujuan PKM ini agar hasil panen dapat dijual dalam bentuk olahan, berupa tepung mocaf dengan maksud agar tidak sulit dijual dan harganya lebih tinggi. Khalayak sasaran adalah yang membutuhkan dan bersedia dibina dalam bisnis mocaf, tujuan akhirnya adalah terbentuknya usaha mocaf bekesinambungan. Metode kegiatannya tutorial dan pelatihan, tutorial pemasaran dan menyisipkan kewirausahaan islami. Berdasarkan hasil pendampingan PKM menunjukkan bahwa terdapat 7 peserta yang serius melakukan bisnis melalui kemitraan dan dipasarkan secara online, sehingga hasil panen termanfaatkan dan terjual karena mocaf dapat bertahan 1 tahun. Harga singkong belum meningkat karena masih dari kebun milik sendiri dan jumlah produksi terbatas. Pemasaran sudah dilakukan secara online, namun belum mampu memenuhi permintaan karena terkendala produksi
\end{abstract}

Keywords: Petani, Mocaf, Harga, Kesejahteraan

\section{Pendahuluan}

Desa Rende secara monografi merupakan daerah yang relatif subur, berbentuk perkebunan dan sawah, dan hampir setiap kebun ditanami singkong, dengan kualitas baik (Kecamatan
Cikalongwetan Dalam Angka, 2018). Suhu di desa Rende berkisar antara 20 sampai dengan 32 derajat celcius (Oktini, 2016: 2). Tanaman singkong sangat cocok pada suhu tersebut. Sejak tahun 2017, Desa Rende ditetapkan sebagai desa wisata berbasis masyarakat 
dan pertanian (Alwasilah, 2017), atas kerjasama antara SITH-Institut Teknologi Bandung dengan Dinas Pariwisata \& Kebudayaan Kabupaten Bandung Barat nomor 073/467/DISPARBUD/2017 dan nomor $\quad 4467 / \mathrm{SPK} / \mathrm{I} 1 . \mathrm{CO} 2 / \mathrm{DN} / 2017$. Berdasarkan hasil penelitian Oktini (2017), ditemukan beberapa potensi dan kondisi lingkungan yang ada di Desa Rende layak untuk dikembangkan menjadi desa wisata, sehingga mampu meningkatkan kesejahteraan masyarakat. Beberapa produk olahan telah dikembangkan atas kerjasama tersebut, seperti bermacam-macam bumbu yang diawetkan, keripik singkong berbagai rasa. Salah satu produk yang memiliki potensi untuk dikembangkan selanjutnya di desa Rende yaitu tepung mocaf atau tepung yang berbahan singkong. Produk tersebut merupakan alternatif diversifikasi yang dipandang strategis dalam menunjang ketahanan pangan, yaitu singkong yang berfungsi sebagai bahan pangan, digunakan untuk bahan dasar aneka makanan (Marsigit, 2010).

Tujuan pengabdian ini sesuai dengan harapan masyarakat baik petani singkong maupun umum. Petani singkong sudah lama mengharapkan agar hasil panennya tidak sulit dijual dan agar harganya lebih tinggi, sementara masyarakat umum mengharapkan dapat memanfaatkan singkong ini menjadi olahan yang bernilai komersil sehingga dapat membantu perekonomian keluarga serta sudah siap berbisnis jika menilainya layak dibisniskan. PKM ini sangat sesuai dengan permasalahan yang dihadapi dan merasa sangat urgen untuk dicarikan solusinya, apalagi sejak pandemi Covid-19 terjadi penurunan pendapatan masyarakat secara keseluruhan, meningkatnya jumlah masyarakat miskin, sulitnya pekerjaan, dsb (Fitriana, 2020). Renstra LPPM 2016-2020 menyatakan bahwa kegiatan PKM menargetkan dan mempercepat kearah upaya pengembangan kelompok masyarakat melalui pembinaan- pembinaan secara dinamis dan berkesinambungan, sehingga dapat mempersiapkan diri dalam menempuh perubahan-perubahan menuju perbaikan dan kemajuan yang sesuai dengan nilai sosial kemasyarakatan yang berlaku di wilayahnya.

Program PKM ini akan diawali dengan kegiatan penyuluhan/tutorial/ literasi yang merupakan proses pendidikan nonformal yang diberikan pada seseorang atau kelompok dengan tujuan agar dapat memecahkan masalahnya sendiri khusus dibidangnya guna meningkatkan kesejahteraan (Agussabti, 2020), sedangkan pelatihan adalah proses belajar untuk membiasakan diri atau memperoleh kecakapan tertentu (Herwina, 2021). Tutorial/literasi yang diberikan yaitu mengenai kreativitas dan inovasi. Kreativitas dapat dikembangkan oleh seseorang melalui kemampuannya dalam menciptakan suatu pemecahan permasalahan yang berkaitan dengan penciptaan gagasan-gagasan yang original dan adaptif terhadap perubahan lingkungan guna pengembangan kondisi yang ada sekarang ini menjadi sesuatu yang lebih baik (Tumiwa dkk, 2021), contohnya pada suatu lingkungan kampus yang awalnya tidak ada tempat foto copy, menjadi ada. Sedangkan, inovasi merupakan sebuah karya baru (Nasution, 2018). Terdapat 2 (dua) syarat inovasi, pertama adalah terkait kebaruan (novelty) atau originalitas. Novelty dalam hal ini adalah sesuatu yang baru dan dapat diciptakan, produk bisa yang benar-benar baru, produk pengembangan berupa pembaruan pada sisi nilai guna, kondisi maupun aplikasi dan lainnya. Syarat yang kedua yaitu improvement, maksudnya adalah secara berkesinambungan produk maupun proses terus ditingkatkan melalui cara yang paling efektif dan efisien (Saragih 2017: 28). Inovasi diimplementasikan pada produk hasil tani, yaitu singkong yang merupakan tanaman wilayah tropis, produksinya melimpah (produktif) dan 
sangat mudah untuk dibudidayakan, sehingga dapat dijadikan sebagai salah satu alternatif makanan pengganti makanan pokok beras, atau pengganti tepung terigu, dan diharapkan dapat meningkatkan ketahanan pangan. Singkong itu sendiri dapat dikembangkan melalui upaya penganekaragaman produk (diversifikasi), salah satunya dengan menciptakan tepung mocaf, yaitu tepung terbuat dari singkong yang difermentasi dengan mikroba seperti Acetobacter xylinum, Rhizopus oryzae dan Saccharomyces cerevisae dan lactobacillus casei (Erismar, 2014: 183). Diversifikasi merupakan upaya yang dilakukan oleh suatu perusahaan melalui penganekaragaman lini bisnis dengan tujuan selain untuk meningkatkan pendapatan perusahaan, juga untuk berjaga-jaga ketika perusahaan tidak mampu hanya mengandalkan satu jenis usaha. Upaya diversifikasi juga dapat dilakukan melalui penciptaan produkproduk beragam yang berasal dari satu jenis bahan baku, misalnya singkong diolah menjadi berbagai macam produk. Produk olahan tersebut memiliki pasar yang berbeda, sehingga kemungkinan rugi itu dapat ditutupi oleh keuntungan dari keuntungan bisnis lainnya (Hanafie, 2010: 213).

Upaya tersebut bertujuan untuk memperluas pasar maupun menciptakan pasar baru (Syah, 2018), sehingga diharapkan dapat meningkatkan konsumsi makanan berbahan tepung mocaf, sehingga permintaan terhadap tepung mocaf bertambah dan berpengaruh positif terhadap meningkatnya harga tepung mocaf.

Harga dibedakan menjadi dua, yakni harga objektif dan harga yang dipersepsikan (Setiawina, 2016). Harga objektif adalah harga aktual suatu produk/jasa, sedangkan harga yang dipersepsikan menunjukkan harga yang disandikan/dikodekan oleh pelanggan. Setelah singkong menjadi tepung mocaf, maka selanjutnya yaitu pemasaran, dapat dilakukan secara online dan offline. Pelatihan mengenai pemasaran tepung mocaf dimaksudkan agar membantu kelancaran pemindahan produk agar cepat sampai kepada konsumen.

Proses produksi tepung mocaf menggambarkan bagaimana bahan dasar singkong diolah menjadi produk tepung yang bernilai guna. Fungsi produksi menunjukkan hubungan antara faktor produksi dengan hasil produksi, dimana hasil produksi (Y) ditentukan oleh faktor produksi (X), hubungan kedua variabel dapat positif maupun negatif. Jika semakin tinggi $\mathrm{X}$, maka semakin tinggi $\mathrm{Y}$, hal ini menunjukkan hubungan positif, sedangkan jika semakin tinggi $\mathrm{X}$ semakin rendah Y. Hal tersebut menunjukkan hubungan negatif. Menurut Pindyck (2009), bentuk matematis dari fungsi produksi ditunjukkan sebagai berikut:

$\mathrm{Y}=\mathrm{f}(\mathrm{X} 1, \mathrm{X} 2, \ldots \mathrm{Xn})$, dimana:

$\mathrm{X}=$ Input faktor produksi

$\mathrm{Y}=$ Hasil Produksi

Profit merupakan selisih antara total pendapatan (Total Revenue/TR) - Total Biaya (Total Cost/TC). Total penerimaan hasil usaha tani merupakan perkalian dari hasil produksi dengan harga jual (Py), dapat digambarkan sebagai berikut:

$\mathrm{TR}=\mathrm{Y}$ x Py.

Biaya yang digunakan oleh petani itu terdiri dari biaya tetap (fixed cost/FC) dan biaya variabel (variabel cost/VC). Biaya tetap merupakan biaya yang tidak mengalami perubahan walaupun jumlah produksi berubah, contohnya peralatan yang dalam jangka panjang cenderung tidak mengalami perubahan, sedangkan biaya variabel merupakan biaya yang berubah sesuai dengan perubahan jumlah produksi, contohnya biaya tenaga kerja dan biaya bahan baku. Penjumlahan VC dan FC merupakan biaya total/Total Cost (TC), jika digambarkan adalah $\mathrm{TC}=\mathrm{FC}$ + VC (Sukirno, 2011).

Mocaf yang telah diproduksi sebaiknya dipasarkan melalui pemasaran online. Pemasaran online (digital) adalah tentang orang, bagaimana 
mereka menggunakan teknologi dan bagaimana kita dapat memanfaatkannya untuk terlibat lebih efektif. Teknologi hanya menyediakan platform yang baru dan menarik. Dalam konteks media sosial, pemasaran media sosial telah menarik perhatian dan minat yang terus meningkat dari merek dan bisnis besar maupun kecil. Situs jejaring media sosial sekarang menerima lalu lintas jejaring tertinggi di seluruh dunia (Alfarizi, 2018) dan sepertiga waktu daring dihabiskan di media sosial (GlobalWeb Index, 2018).

Pemasaran konvensional untuk tepung mocaf juga masih dibutuhkan mengingat pasarnya luas. Pemasaran konvensional dapat berupa penjualan langsung maupun melalui perantara dengan memanfaatkan ritel-ritel yang ada (Kotler \& Keller, 2016). Kerangka bauran pemasaran, secara tradisional dikenal sebagai 4 Ps (Produk, Promosi, Harga, dan Tempat), adalah teori manajemen pemasaran yang dominan dan alat manajerial yang banyak digunakan yang membantu mengidentifikasi komponen utama suatu produk (Fan et al., 2015).

Model 4 Ps dengan menambahkan 3 Ps, termasuk Peserta (atau Orang), Bukti Fisik, dan Proses untuk produk layanan. Dibandingkan dengan 4 Ps, model 7 Ps memberikan kerangka kerja yang lebih komprehensif dan terperinci dalam menganalisis bauran pemasaran produk jasa (Loo \& Leung, 2018). Selain kemampuannya untuk menilai elemen pemasaran kritis dari suatu produk jasa, Model 7 Ps juga dapat diterapkan ke area lain sebagai kerangka pemasaran generik dalam pertanyaan seperti analisis isi kualitatif (Loo \& Leung, 2018), studi survei (Harrington et al., 2017) dan analitik data besar untuk intelijen bisnis atau pemasaran (Fan et al., 2015). Saluran konvensional untuk memasarkan tepung mocaf dapat disebarkan sendiri, dijual kembali kepada pedagang, atau dikonsinyasi melalui warung, pasar tradisional maupun pasar modern. Harapan terakhir dari aktivitas pemasaran adalah terciptanya kepuasan pelanggan. Melalui pelatihan ini, harapan petani, masyarakat, dan pemerintah dapat terwujud yakni meningkatkan pendapatan, sesuai dengan perubahan arah pembangunan pemerintah yang tertuang dalam RPJMD kabupaten Bandung Barat yang lebih memfokuskan pada peningkatan kegiatan ekonomi masyarakat dalam menghadapi pandemi covid-19 yang merupakan tragedi baru dalam peradaban manusia dan menghasilkan pandemi global yang sedang berlangsung (Hui et al., 2020). Covid-19 menyebar terutama diantara orang-orang yang jaraknya berdekatan dan melakukan kontak, penyebarannya dapat melalui batuk, bersin, atau berbicara (WHO, 2020). Penelitian terbaru mengungkapkan bahwa kebijakan jarak fisik yang disebabkan oleh penyakit virus korona pada tahun 2019 telah mempengaruhi sosial ekonomi (Fernandes, 2020; Nicola et al., 2020) dan rantai pasokan (Ivanov, 2020).

Desa Rende memiliki tanaman singkong cukup luas, terdiri dari tanah desa dan masyarakat, namun mengeluhkan sulitnya menjual hasil panennya yang sebagian dijual melalui tengkulak seharga Rp500 per kg, sedangkan sebagian lagi yang tidak terjual digunakan sebagai bahan pakan hewan (Fitriana, 2020).

Tepung mocaf merupakan tepung berbahan singkong, tapi berbeda dengan tepung tapioka, dimana tepung tapioka komponen utamanya pati sehingga kandungan proteinnya sangat sedikit bahkan tidak ada (Erismar, 2014). Sedangkan, tepung mocaf itu karena seluruh bagian singkong diolah sehingga masih mengandung protein (Rosmeri, 2013). Kandungan kalsium dalam mocaf lebih tinggi dibanding tepung gandum maupun padi, tepung mocaf lebih mudah dicerna karena tidak mengandung asam sianida. Tepung mocaf sangat baik untuk penderita autis karena tidak mengandung gluten. Tepung 
mocaf dapat bertahan sampai 1 tahun dan dapat digunakan sebagai pengganti tepung terigu untuk membuat berbagai macam makanan seperti kue-kue, aneka macam snack, campuran bahan terigu, gorengan dsb, tepung mocaf dapat dijual dan menghasilkan pendapatan bagi masyarakat (Pratiwi, 2014).

\section{Metode Ilmiah}

Metode pendekatan masalah didasari oleh pentingnya pemahaman khalayak sasaran terhadap keseluruhan aspek-aspek yang terkait dengan kegiatan PKM.

Metode pelaksanaan terdiri dari :

\section{Rencana Kegiatan}

a. Sosialisasi Program: Memberikan gambaran kepada Mitra tentang usaha tepung mocaf dengan berbagai permasalahan hingga mencapai keberhasilan, dari mulai produksi sampai pemasaran.

b. Rencana Tindakan: Merumuskan rincian aktivitas pembinaan secara detail pada Mitra karena setiap langkah pembinaan membutuhkan partisipasi Mitra.

c. Penyusunan Rencana Usaha: Rencana usaha hasil pertanian perlu disusun sebagai bagian dari proses usaha komersial. Rencana usaha disusun sebagai arah kegiatan usaha serta akan menjadi pendoman dalam monitoring dan evaluasi perkembangan usaha.

d. Pengenalan Potensi Singkong sebagai sumber bahan lokal yang berpotensi untuk dikembangkan: Singkong berkualitas adalah singkong yang baru dipanen, harus langsung diproduksi/diolah menjadi tepung maupun olahan lain. Maksimal 3 hari setelah dipanen tidak menimbulkan perubahan warna dan rasa. Singkong yang dihasilkan di wilayah Jawa Barat kualitasnya baik, disebut dengan singkong jenis mentega, berwarna kekuningan dan sering dijadikan bahan peuyeum. Namun, harga singkong hasil pertanian di desa Rende tetap rendah yaitu Rp500, sedangkan di wilayah Jawa Tengah mencapai Rp1.600. Kondisi ini terjadi karena petani tidak mengetahui bahwa produk singkong itu dapat dikembangkan menjadi produk tepung mocaf yang kegunaannya lebih banyak, yaitu sebagai bahan pengganti terigu atau pencampur terigu, dapat dibuat sebagai bahan aneka makanan kue-kue dan snack dengan metode pengolahan fermentasi untuk menghasilkan tepung yang baik, rasanya tidak pahit, warnanya putih, tidak berbau, tidak menimbulkan pusing, dan kembung setelah dikonsumsi.

e. Pengadaan, yaitu pengadaan singkong yang baik.

f. Pengadaan, yaitu pengadaan bahan fermentasi.

g. Pengolahan, yaitu pembuatan tepung mocaf.

h. Manajemen Pemasaran: Pemasaran tepung mocaf diawali dengan tes pasar terlebih dahulu. Tes pasar dilakukan saat program PKM berlangsung.

Adapun susunan acara kegiatan adalah sebagai berikut:

a. Membagi kelompok pelatihan berdasarkan tempat tinggal dimana 1 kelompok terdiri dari 5 orang dengan lokasi tempat tinggal berdekatan.

b. Pertemuan pertama diawali dengan pre test, kemudian dilanjutkan dengan pemberian teori kewirausahaan (kreativitas dan inovasi), simulasi menghasilkan ide-ide kreativitas dan inovasi, teori tentang pembukuan sederhana, informasi tentang tepung mocaf, teori pembuatan tepung mocaf baik menggunakan fermentasi maupun tanpa fermentasi, teori pemasaran 
mocaf secara online dan offline. Pada pertemuan pertama juga akan dipamerkan beberapa contoh hasil olahan tepung mocaf yang sudah diolah oleh tim pengusul. Pada pertemuan pertama, kepada setiap kelompok akan disampaikan pemberian tugas, yaitu melakukan percobaan di rumah ketua kelompok, kemudian melakukan percobaan membuat olahan makanan, dimana tepung mocafnya dibawa saat pertemuan kedua dan membawa hasil olahan dalam bentuk makanan.

c. Pada pertemuan kedua, setiap kelompok menyajikan hasil olahannya, baik dalam bentuk tepung mocaf maupun hasil olahan makanannya, kemudian masingmasing saling mengevaluasi dan menyampaikan pendapatnya mengenai rasa, warna, kualitas serta efek yang ditimbulkan setelah dikonsumsi. Pada pertemuan kedua ini akan disampaikan kepada setiap kelompok untuk melanjutkan dengan menawarkan kepada orang-orang terdekat maupun tetangga terlebih dahulu, dimana yang ditawarkannya itu tepung mocaf, namun akan lebih efektif jika disertai dengan sampel produk olahan yang dapat dirasakan oleh calon konsumen. Pertemuan ke dua harus berjarak cukup jauh waktunya dari pertemuan pertama karena ditengah waktu tersebut peserta harus mengerjakan tugas, yaitu melakukan eksperimen pembuatan tepung mocaf dan membuat makanan olahan berasal dari tepung mocaf yang dihasikan. Perlunya waktu karena pembuatan tepung mocaf membutuhkan waktu sekitar satu minggu.

d. Pertemuan ketiga, tim pengusul akan melakukan evaluasi dan sharing tentang pelatihan pembuatan tepung mocaf ini. Pada pertemuan ketiga ini juga dilakukan post test.

\section{Metode Pendekatan Masalah}

Berikut ini akan digambarkan proses pendekatan masalah untuk

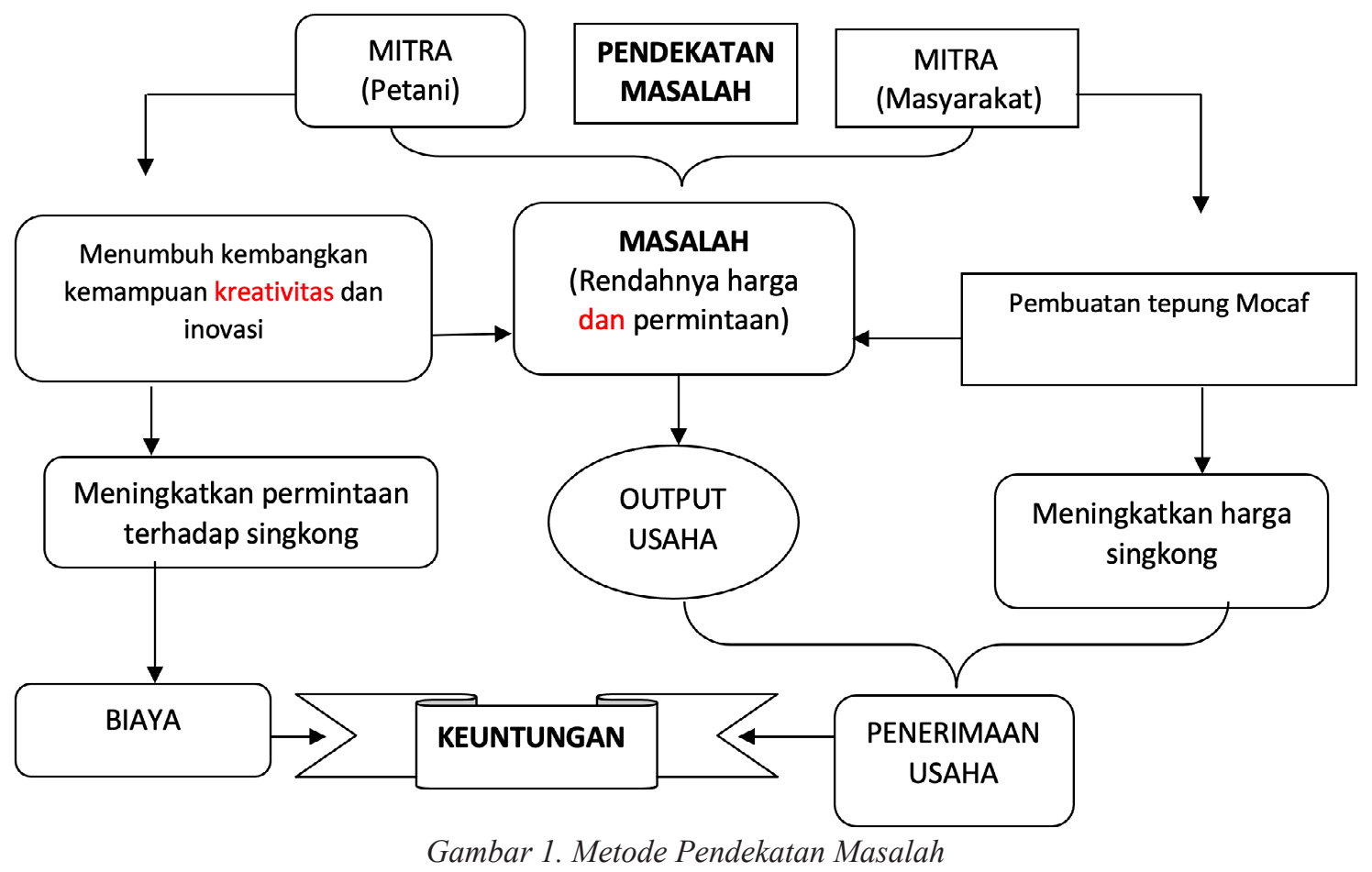

ISSN 1693-699X | EISSN 2502-065X 
membantu masyarakat sebagai berikut: Transfer IPTEKS yang dilakukan Tim PKM Unisba pada setiap tahapan menggunakan prinsip bahwa setiap inovasi yang diterima oleh Mitra melalui proses: Mendengar, Mengetahui, Mencoba, Mengevaluasi, Menerima, Meyakini, Melaksanakan. Melalui proses-proses ini diharapkan inovasi dapat diadopsi secara berkesinambungan, serta target sasaran mempunyai kemampuan untuk melakukan analisis terhadap perkembangan usahanya, serta mampu mengembangkan inovasi yang telah dikuasainya. Agar setiap proses berlangsung dengan baik, maka penyampaian inovasi kepada Mitra, ditempuh melalui tahapan penjelasan, diskusi, praktik serta pembimbingan.

Secara umum proses pendekatan untuk membantu Mitra dalam penyuluhan dan pelatihan pembuatan tepung mocaf dapat dipaparkan dalam Gambar 1.

Gambar 1 menunjukkan bahwa solusi permasalahan petani singkong di desa Rende dimulai dari tahap pendekatan kepada mitra, yaitu petani itu sendiri guna menggali informasi yang menjadi penyebabnya dan masyarakat lainnya guna mendukung peningkatan permintaan terhadap singkong hasil petani, dimana masyarakat nonpetani akan diarahkan untuk menekuni bisnis berbahan dasar singkong. Permasalahan tersebut dapat diatasi melalui peningkatan kemampuan/ menumbuh kembangkan hasil panen singkong menjadi produk turunan yang lebih besar manfaatnya dan lebih luas pasarnya, salah satunya adalah tepung mocaf karena produk tersebut pasarnya tumbuh dan didukung oleh pemasaran yang lebih mudah melalui aplikasi online yang dapat menjangkau secara luas. Melalui bisnis tepung mocaf, dapat menyebabkan permintaan meningkat sehingga dalam jangka panjang harga singkong meningkat yang berimplikasi pada meningkatnya kesejahteraan. Petani dapat menghemat biaya bahan baku ketika dipasok dari kebun sendiri, sehingga penerimaan dan keuntungan diperoleh lebih banyak.

\section{Hasil dan Pembahasan}

Pada hari selasa, 02 Februari 2021, tim PKM mengadakan penyuluhan dan pelatihan pembuatan tepung mocaf kepada para petani singkong di Rw 13 kampung Malingping. Jumlah peserta melebihi batas yaitu sebanyak 40 dengan usia yang beragam, dari mulai orang dewasa hingga remaja, namun peserta wanita lebih banyak daripada pria. Pada sesi pertama, dimulai dengan pelatihan pembuatan tepung mocaf terlebih dahulu. Pada sesi ini disampaikan manfaat tepung mocaf bagi kesehatan, hal ini disampaikan mengingat tepung mocaf belum banyak yang menggunakan, umumnya masyarakat menggunakan tepung terigu, tepung tapioka, tepung aren yang tersebar di seluruh tempat penjualan. Konsumen tepung mocaf masih terbatas di wilayah Jawa tengah, awalnya di Jawa Timur karena di wilayah tersebut sudah lebih dulu mengembangkan bisnis tepung mocaf, sedangkan di Jawa Barat masih sedikit pabriknya. Banyak konsumen berasal dari kelompok yang memperhatikan kesehatan karena tepung mocaf bermanfaat terutama untuk penderita epilepsi dan obesitas, dll. Oleh karena itu, sangat penting disampaikan tentang manfaat-manfaat tepung mocaf bagi kesehatan sehingga dapat menjadi alternatif pengganti bahan makanan pokok lainnya. Pada sesi ini juga disampaikan bahwa sebaiknya mengembangkan bahan makanan pokok yang berbasis kearifan lokal, yang mana singkong ini merupakan bahan makanan penting, namun pengolahannya masih terbatas, padahal dapat diolah seperti halnya tepung terigu yang dapat digunakan untuk membuat aneka olahan yang bergizi dan bahan campuran yang dihasilkan memiliki rasa lebih baik. Selain itu, singkong mudah ditanam dan murah biaya pemeliharaannya, hanya 
membutuhkan lahan yang luas. Lebih baik tepung mocaf ini dikembangkan karena di Indonesia mudah sekali menanam singkong. Hal ini sesuai dengan pendapat yang mengatakan bahwa lebih baik bahan makanan pokok itu dihasilkan dari tanah sendiri dibanding mengandalkan negara lain.

Pelatihan tepung mocaf disampaikan kepada para peserta berupa pemberian contoh bagian-bagian pengolahan barang setengah jadi, yaitu chips-chips yang sudah direndam melalui proses fermentasi terlebih dahulu telah dilakukan oleh tim di rumah, kemudian diperagakan di tempat pelatihan sambil dijelaskan bagaimana proses fermentasi itu dilakukan. Proses fermentasi ini membutuhkan bahan fermentasi, sedangkan bahan fermentasi itu banyak jenisnya, dalam kegiatan ini diberi contoh Bimo-CF karena harganya lebih murah dibanding merek lain. $1 \mathrm{~kg}$ singkong dapat dikonversi menjadi 3 ons tepung mocaf (Erismar, 2014). Konsumen Pada sesi pelatihan tidak ada aktivitas fermentasi karena proses fermentasi membutuhkan waktu 24 jam, sehingga tidak mungkin diperagakan di dalam acara pelatihan, namun dijelaskan bahwa chip-chip yang sudah difermentasi kemudian di jemur sampai kering, proses penjemuran dapat menghabiskan waktu 2 sampai 3 hari tergantung cuaca. Selanjutnya, chip-chip yang sudah kering dibuat menjadi tepung, bisa ditumbuk maupun menggunakan mesin tepung. Tim PKM membawa contoh bahan fermentasi yaitu Bimo-CF dan tepung mocaf yang sudah jadi baik yang dibuat sendiri oleh tim PKM maupun yang dibeli dari produsen tepung mocaf yang sudah ada. Selain itu, sebagai tambahan wawasan, diberikan contoh-contoh produk olahan dari tepung mocaf yang beraneka ragam seperti kue tart, eggroll, kerupuk, keripik, kue basah, kue-kue kukus, rasi (beras singkong) serta snack yang jumlahnya sangat variatif dan menarik. Sebagian dibuat atas pesanan tim PKM, sebagian lagi diperoleh dari pusat olahan singkong yaitu kampung Cireundeu - Cimahi. Harapannya, petani dan masyarakat terinspirasi dengan melihat produk-produk tersebut sehingga timbul pemahaman bahwa tepung mocaf itu dapat dibuat berbagai makanan yang menarik dan bergizi seperti halnya tepung terigu. Dengan demikian, timbul minat untuk menekuni bisnis tepung mocaf maupun produk turunannya.

Pelatihan pembuatan tepung mocaf ini juga ditambah dengan penjelasan mengenai pembuatan tanpa proses fermentasi, namun hanya menggunakan air sebagai bahan untuk menghilangkan bau. Proses perendaman membutuhkan waktu 3 malam 3 hari dan sering mengganti air rendaman agar tidak menimbulkan bau. Penjelasan dapat diterima dan dimengerti karena masyarakat sudah mengenal pembuatan gaplek, walaupun prosesnya berbeda namun mudah dimengerti. Hal ini diindikasikan dengan aktifnya peserta yang bertanya terkait pembuatan tepung mocaf maupun produk turunannya. Pada sesi akhir pelatihan, masingmasing peserta diberi bahan fermentasi dan melakukan eksperimen pembuatan tepung mocaf dalam pendampingan serta diberi contoh-contoh produk turunan guna memperluas wawasan agar muncul inspirasi dari masing-masing peserta.

Berikut ini gambaran analisis usaha tepung mocaf memanfaatkan lahan sendiri sehingga tidak ada biaya sewa lahan.

a. Biaya modal

- Bangunan dan bak perendaman, masa pakai 15 tahun Rp. 10.000.000

- $\quad$ Mesin chip/tepung masa pakai 5 tahun Rp. 1.500 .000

- Alas penjemuran 15.000 x 100 buah $=$ Rp. 1.500 .000

- Total Biaya Investasi Rp. 13.000.000

b. Biaya produksi

- $\quad$ Bahan baku singkong Rp 500/kg x $5000 \mathrm{~kg}=$ Rp. 2.500 .000

- Bahan Fermentasi Rp. 100 x 1500 
$=$ Rp. 150.000

- $\quad$ Biaya tenaga kerja pengupasan Rp. $15000 /$ ton $\times 5$ ton $=$ Rp. 75.000

- Biaya pemotongan (chiping) \& pencucian Rp. 5000/ton $\times 5$ ton $=$ Rp. 25.000

- $\quad$ Biaya pengeringan Rp. 25.000/ton x 5 ton $=$ Rp. 125.000

- $\quad$ Listrik Rp. 75.000

- Total Biaya produksi $=\mathrm{Rp}$. 2.950 .000

Jika $1 \mathrm{~kg}$ singkong menghasilkan 5 ons tepung mocaf, maka 5 ton $(5000 \mathrm{~kg})$ singkong menghasilkan 15.000 ons atau $250 \mathrm{~kg}$, sehingga $1 \mathrm{~kg}$ biaya memerlukan biaya produksi sekitar Rp. 11.800. Jika mark up (profit) yang diinginkan sebesar $20 \%$ (Rp. $11.800 \times 20 \%=$ Rp. 3260), maka harga jual sebesar Rp. 14.160 (Rp. $11.800+$ Rp. 3.260), atau dibulatkan menjadi Rp. 15.000/kg. Dengan demikian, produsen mocaf mendapatkan keuntungan sekitar Rp. 3.200 per kg. Jika yang dijual adalah $250 \mathrm{~kg}$, maka keuntungan dari produksi 5 ton itu adalah Rp. 800.000. Perhitungan diatas menggunakan asumsi bahwa produsen mocaf membeli bahan baku singkong dari petani. Apabila singkongnya diproduksi sendiri maka tentu saja keuntungannya adalah sebagai berikut:

- $\quad$ Biaya produksi 5 ton $=$ Rp. 450.000

- Pendapatan yaitu $250 \mathrm{~kg}$ x Rp.

$15.000=$ Rp. $3.750 .000-$ Rp. $450.000=$ Rp. 3.300 .000 .

Jadi, jika petani hanya menjual singkong dia akan mendapatkan Rp. 2.500.000, namun bila menjualnya dalam bentuk tepung mocaf, maka ada kesempatan mendapatkan lebih minimal Rp. 3.300.000. Di Tokopedia, produsen menjualnya bisa sampai Rp. 32.000 per kg sehingga keuntungan dapat mencapai Rp. 7.550 .000 (Rp. 32.000 x $250 \mathrm{~kg}-$ Rp. 450.000). Jika membeli singkong dari petani maka keuntungan dari 5 ton itu adalah Rp. $2.950 .000: 250 \mathrm{~kg}=$ Rp. 11.800. Rp. $32.000-$ Rp. $11.800=$ Rp. 20.200 sehingga keuntungan $=\mathrm{Rp}$. $20.200 \times 250=$ Rp. 5.050.000. Namun demikian, masih harus membayar biaya online-nya yang besarannya berbedabeda.

Tahapan selanjutnya adalah penyuluhan mengenai pemasaran tepung mocaf melalui saluran online dan saluran konvensional. Penjelasan masih terbatas pada latar belakang mengapa pemasaran online penting dalam menjalankan bisnis. Hal ini dilatarbelakangi karena strategi pemasaran online sangat penting guna mendukung efektifitas penjualan, walaupun biasanya usaha mikro melakukannya secara manual, spontan, tidak fokus dan seadanya. Perencanaan yang detail dan terkesan berbelit-belit dianggapnya menyulitkan sehingga lebih memilih yang lebih fleksibel dan mudah. Melalui pemasaran online merupakan sarana untuk memperkenalkan secara luas dan global kepada konsumen di wilayah dekat dan jauh bahkan di luar negeri. Pemasaran online juga dapat mengidentifikasi konsumen, sehingga UKMdapatmemenuhiharapankonsumen. Pemasaran merupakan roda inti, jika tanpa adanya strategi yang baik maka penjualan akan sulit tercapai. Strategi pemasaran online juga berperan dalam membangun merek serta menciptakan komunikasi dengan konsumen, sehingga dapat mempertahankan dan menjaga keberlangsungan usaha dalam jangka panjang. Berdasarkan pengamatan menunjukkan bahwa kalangan muda dari peserta sudah mengenali aplikasi-aplikasi online, namun belum memanfaatkannya untuk bisnis, baru sebatas menggunakan untuk media berbelanja saja.

Pemasaran konvensional juga dijelaskan dalam kegiatan PKM ini mengingat hingga sekarang masih ada strategi-strategi konvensional yang masih eksis digunakan, bahkan strategi tersebut memberikan hasil yang efektif. Jenis pemasaran konvensional yang dijelaskan seperti penggunaan kartu nama, menjalin networking, menggunakan flyer, membuat merek. Khusus untuk tepung mocaf dapat juga memanfaatkan 
pedagang-pedagang di pasar tradisional guna konsinyasi atau warung-warung, serta pedagang-pedagang gorengan dan pabrik kue.

Sesi lainnya diisi dengan materi keislaman yang relevan dengan perdagangan, hal ini dilakukan guna mendidik masyarakat agar dalam melakukan bisnis senantiasa mengikuti ajaran Nabi Muhammad SAW serta memupuk semangat berkarya dan berusaha sebagai bagian dari ibadah, sebagaimana diperintahkan Allah SWT sehingga PKM ini dilakuan dengan mengintegrasikan dan menginternalisasikan nilai-nilai islam sebagaimana visi misi Unisba.

Pendampingan dilakukan pada peserta yang mengikuti kegiatan pelatihan, namun tidak dilakukan terhadap seluruh peserta melainkan hanya pada peserta yang serius ingin menekuni dan mau melakukan eksperimen bisnis tepung mocaf secara serius. Berdasarkan pengamatan, terdapat 5 orang yang serius menjalankan bisnis tepung mocaf, keseriusannya terbukti dalam melakukan eksperimen. Kegiatan eksperimen ada yang dilakukan sebanyak 5 kali, 6 kali, sampai 8 kali. Satu orang peserta yang intensif melakukan komunikasi dengan tim PKM yaitu bernama Ahmad, komunikasi ini berjalan guna melakukan pemantauan dan evaluasi. Melalui Ahmad ini tim PKM mengetahui bagaimana kondisi peserta, apakah melakukan eksperimen atau tidak. Berdasarkan informasi, seluruh peserta yang diberi bahan fermentasi mengadakan eksperimen dari mulai proses fermentasi sampai menjadi tepung mocaf. Ada yang melakukannya hanya sampai 1 kali eksperimen, setelah menjadi tepung mencoba membuat snack. Ada yang melakukan percobaan namun mengalami kegagalan, kemudian dicoba lagi beberapa kali, bahkan ada yang melakukan percobaan sampai 8 kali dan menghabiskan cukup banyak singkong segar. Ada juga yang gagal, menimbulkan bau tidak sedap tercium hingga rumah tetangga. Setelah $7 \mathrm{kali}$ mengalami kegagalan, percobaan ke- 8 sukses membuat aneka snack. Hasilnya dikatakan bahwa tepung mocaf sangat cocok digunakan sebagai bahan kue menggunakan teknik kukus seperti kue apam, bolu kukus dsb, sedangkan pembuatan gorengan, lebih menghasilkan rasa yang lebih baik jika dicampur dengan tepung mocaf.

Berdasarkan hasil eksperimen, terdapat perbedaan rasa dan aroma tepung mocaf yang dibuat oleh masingmasing peserta, hal ini disebabkan karena proses yang sedikit saja berbeda, maka akan menghasilkan tepung mocaf yang berbeda pula, dan sangat tergantung pada cuaca. Apabila cuaca baik, sinar matahari terik, akan menghasilkan tepung dengan warna yang putih bersih serta rasa yang lebih baik.

Hasil eksperimen yang sudah tidak mengalami kegagalan tersebut, kemudian ditawarkan kepada beberapa pedagang gorengan untuk dijadikan bahan baku campuran. Ada juga yang dikirim ke Jakarta kepada produsen kue untuk dilakukan percobaan dan responnya baik, sehingga melakukan order kembali walaupun dalam jumlah yang masih sedikit, kurang lebih $20 \mathrm{~kg}$ setiap melakukan order. Sementara itu, pedagang gorengan juga melakukan order dalam jumlah yang masih sedikit kurang lebih $2 \mathrm{~kg}$ dengan waktu 2 hari. Pemasaran tepung mocaf memerlukan waktu yang cukup panjang karena masih harus mengedukasi calon konsumen sehubungan belum banyak mengenal, selain itu pada saat memperkenalkan mocaf harus disertai dengan sampel karena umumnya calon konsumen yang ditemui belum mengenalnya.

PKM ini menghasilkan 7 usaha kecil tepung mocaf. Bahkan 1 dari 7 pengusaha, selain memproduksi sendiri, juga menjadi penampung mocaf hasil olahan pengusaha lainnya. Hal ini dilakukan selain karena membutuhkan 
pasokan yang lebih banyak, juga untuk membantu pengusaha yang belum mampu memasarkan secara lebih besar dan lebih luas. Pengusaha ini memberikan merek tepung mocafnya, yaitu Adriza mocaf dan sudah mampu menjual secara online melalui lazada, setiap hari melayani 1-5 pesanan paket.

\section{Kesimpulan dan Saran}

\section{Kesimpulan}

Melalui kegiatan PKM ini, masyarakat diberikan pelatihan pembuatan tepung mocaf, dengan tujuan agar hasil panen singkong tidak hanya dijual dalam bentuk bahan mentah saja karena berharga sangat murah, namun dibuat produk olahan setengah jadi sebagai diversifikasi usaha melalui produk mocaf ini cakupan pasarnya semakin luas, sehingga masyarakat berkesempatan meningkatkan pendapatan keluarganya. Meluasnya pasar tepung mocaf ini akan berdampak pada meningkatnya kebutuhan pasar terhadap singkong, sehingga hal ini akan berdampak pula pada naiknya harga singkong yang dihasilkan oleh petani. Dengan demikian, petani juga dapat meningkat kesejahteraannya.

Pada kegiatan PKM ini juga diberikan penyuluhan mengenai pemasaran online, mengingat sangat pentingnya digital marketing sekarang ini. Tujuannya untuk mempercepat perluasan cakupan pasar, mengingat pasar tepung mocaf itu lebih spesifik yaitu konsumen yang sangat teliti dalam menjaga kesehatannya, terutama konsumen yang berada di kota besar. Penyuluhan lainnya yaitu kewirausahaan, dengan tujuan memberikan semangat dan inspirasi agar dapat kreatif dan inovatif. Penyuluhan dilengkapi dengan etika berbisnis menurut islam, dengan tujuan agar dalam setiap melakukan aktivitas usaha senantiasa berpedoman pada Al-quran dan Hadist serta mencontoh rosululloh SAW guna mendapatkan hasil yang halal dan berkah.

\section{Saran}

Berdasarkan kesimpulan diatas, terdapat beberapa saran berikut:

a. Harga singkong yang sangat rendah perlu diupayakan agar meningkat melalui penciptaan diversifikasi produk, dimana dapat dijadikan produk setengah jadi maupun produk jadi, dengan tujuan agar nilainya lebih tinggi dan jangkauan konsumen lebih luas.

b. Kemampuan petani dan masyarakat sangat terbatas, baik dari sisi kemampuan menghasilkan gagasan pengembangan singkong maupun dalam hal proses produksi tepung mocaf, khususnya dimana tidak semua masyarakat dapat dengan mudah menghasilkan tepung mocaf yang baik. Oleh karena itu, perlu diadakan pelatihan-pelatihan yang lebih fokus kepada upaya menghasilkan tepung mocaf yang lebih baik dengan mendatangkan narasumber kompeten. Diantara peserta, ada yang sudah mampu menghasilkan tepung mocaf layak jual bahkan lebih baik dibandingkan dengan tepung mocaf yang sudah ada di pasaran, sehingga peserta tersebut dapat dijadikan sebagai narasumber.

c. Berdasarkan pengamatan, peserta masih membutuhkan pendampingan intensif terutama peserta yang sangat serius menekuni bisnis tepung mocaf. Bagi peserta yang sudah mampu menghasilkan tepung yang bagus, masih membutuhkan bantuan pemasaran ke pasar yang lebih luas melalui pemasaran online. Oleh karena itu, pada PKM selanjutnya akan diberikan pelatihan pemasaran online melalui pemanfaatan aplikasi Taniku, Bukalapak, Shoope, Tokopedia, dan media sosial termasuk 
pengurusan perizinan. Kebutuhan lainnya, yaitu peningkatan jumlah produksi. Mengingat pesanan semakin meningkat karena ada satu pengusaha yang sudah mampu menerobos pasar secara online melalui aplikasi Lazada, sehingga memerlukan mesin yang lebih baik yang berkapasitas besar.

\section{DAFTAR PUSTAKA}

Agussabti. (2020). Penyuluhan Pertanian Berbasis Syariah. Syah Kuala. University Press.

Alfarizi, Moh Khory., Amri Mahbub. Tempo.Co. 08 Mei 2018.

Erismar, Amri., Putri, Pratiwi. (2014). Pembuatan Mocaf (Modified Cassafa Flour) Dengan Proses Fermentasi menggunakan beberapa jenis ragi. Jurnal Pelangi Research of Education and Development. 6(2), 182-191.

Fan, S., Lau, R. Y. K., \& Zhao, J. L. (2015). Demystifying Big Data Analytics for Business Intelligence Through the Lens of Marketing Mix. In Big Data Research, 02(006).

Fernandes, N. (2020). Economic Effects of Coronavirus Outbreak (COVID-19) on the World Economy. SSRN Electronic Journal, 10(2139).

GlobalWebIndex. (2018). Gwi Social. WHO.(2020).Q\&A on Coronavirus (COVID-19). Who

Harrington, R. J., Ottenbacher, M. C., \& Fauser, S. (2017). QSR brand value: Marketing mix dimensions among McDonald's, KFC, Burger King, Subway and Starbucks. International Journal of Contemporary Hospitality Management, 10(06), 215-300.

Hanafie, Rita. (2010). Pengantar Ekonomi Pertanian. Andi, Yogyakarta

Herwina, Wiwin. (2021). Anaisis Modelmodel Pelatihan. CV Bayfa Cendikia Indonesia. Madiun Jawa
Timur.

Hui, D. S., I Azhar, E., Madani, T. A., Ntoumi, F., Kock, R., Dar, O., Ippolito, G., Mchugh, T. D., Memish, Z. A., Drosten, C., Zumla, A., \& Petersen, E. (2020). The continuing 2019-nCoV epidemic threat of novel coronaviruses to global health — The latest 2019 novel coronavirus outbreak in Wuhan, China. In International Journal of Infectious Diseases, 1(9), 1016.

Ivanov, D. (2020). Predicting the impacts of epidemic outbreaks on global supply chains: A simulationbased analysis on the coronavirus outbreak (COVID-19/SARSCoV-2) case. Transportation Research Part E: Logistics and Transportation Review.

Kecamatan Cikalongwetan Dalam Angka. (2018). Badan Pusat Statistik Kabupaten Bandung Barat. Bandung Barat

Kotler, P., \& Keller, K. L. (2016). Marketing Mangement. In Pearson Edition Limited. New Jersey.

Loo, P. T., \& Leung, R. (2018). A service failure framework of hotels in Taiwan: Adaptation of 7Ps marketing mix elements. Journal of Vacation Marketing.

Marsigit., Wuri. (2010). Pengembangan diversifikasi produk pangan olahan lokal Bengkulu untuk menunjang ketahanan pangan berkelanjutan. Agritech, 30(4), 256-264.

Nasution, Arman Hakin \& Hermawan Kartajaya. (2018). Inovasi. Andi. Yogyakarta.

Nicola, M., Alsafi, Z., Sohrabi, C., Kerwan, A., Al-Jabir, A., Iosifidis, C., Agha, M., \& Agha, R. (2020). The socio-economic implications of the coronavirus pandemic (COVID-19): A review. In International Journal of Surgery.

Alwasilah, Mentari. (2017). Desa RendeDesa Wisata Berbasis Pertanian 
dan Masyarakat. Berita.

Oktini, Dede R. (2017). Pembinaan manajemen zooteknis pada kelompok usahatani cidole desa Rende Cikalongwetan Bandung Barat. Prosiding SNaPP : Sosial, Ekonomi dan Humaniora, 7(2).

Renstra LPPM Unisba 2016-2020. (2020). LPPM Unisba. Bandung.

Rosmeri, Vinsensia Iva \& BNM. (2013). Pemanfaatan tepung umbi Gadung (Dioscorea Hispida Dennst) dan tepung mocaf (modified cassava flour) sebagai substitusi dalam pembuatan mie basah, mie kering, mie instan. Jurnal teknologi kimia dan industri, 2(2), 246-256.

Saragih, R. (2017). Membangun usaha kreatif, inovatif dan bermanfaat melalui penerapan kewirausahaan sosial. Jurnal Kewirausahaan, 3(2), 26-34.

Setiawina, Nyoman. Djinar. (2016). Harapan Rasional Ekonomi Makro. ANDI. Yogyakarta.

Sukirno,S. 2011. Mikro Ekonomi Teori Pengantar. Edisi ketiga. P.T Raja Grafindo Persada. Jakarta.

Syah, Dahrul. (2018). Riset untuk memberdayakan potensi lokal. IPB Press. Bogor.

Tumiwa, Krueger Kristanto dkk. (2021). Tetap Kreatif Dan Inovatif Di Tengah Pandemi Covid-19. PT. Nasya Expanding Manajemen. Pekalongan Jawa Tegah. 